(C) Group of authors, 2018

UDC 616.5-002.92-007.23-092-091-08

DOI - https://doi.org/10.14300/mnnc.2018.13106

ISSN - 2073-8137

\title{
LINEAR SKIN ATROPHY: CURRENT INFORMATION AND MODERN APPROACHES TO THE EXTERNAL THERAPY
}

Tishchenko A. L., Gorskii V. S., Sergeeva N. S.

Medical Institute of People's Friendship University of Russia, Moscow, Russian Federation

\section{АИНЕЙНЫЕ АТРОФИИ КОЖИ: АКТУААЬНАЯ ИНФОРМАЦИЯ И СОВРЕМЕННЫЕ ПОАХОАЫ К НАРУЖНОЙ ТЕРАПИИ}

\author{
А. А. Тищенко, В. С. Горский, Н. С. Сергеева \\ МеАицинский институт Российского университета Аружбы нароАов, \\ Москва, Российская ФеАерация
}

The article presents literature data on the methods of correction of linear atrophy of the skin (striae). This pathology is widespread in both sexes. The decline in the quality of life in this disease occurs largely due to the presence of a cosmetic defect. To date, there is no universal therapeutic approach for the correction of stretch marks. In this article available literature data on the problem of linear atrophy of the skin has been summarized.

Keywords: stretch marks, ethiopathogenesis, topical therapy

Приведены данные литературы относительно методов коррекции линейных атрофий кожи (стрий). Патология широко распространена у лиц обоего пола. Снижение качества жизни при данном заболевании происходит в большей степени из-за наличия косметического дефекта. На сегодняшний день не существует универсального терапевтического подхода для коррекции стрий. Обобщены современные данные литературы по проблеме линейных атрофий кожи.

Ключевые слова: стрии кожи, этиопатогенез, местное лечение

For citation: Tishchenko A. L., Gorskii V. S., Sergeeva N. S. LINEAR SKIN ATROPHY: CURRENT INFORMATION AND MODERN APPROACHES TO THE EXTERNAL THERAPY. Medical News of the North Caucasus. 2018;13(3):566-571. DOI - https://doi.org/10.14300/mnnc.2018.13106

Для цитирования: Тищенко А. Л., Горский В. С., Сергеева Н. С. ЛИНЕЙНЫЕ АТРОФИИ КОЖИ: АКТУАЛЬНАЯ ИНФОРМАЦИЯ И СОВРЕМЕННЫЕ ПОДХОДЫ К НАРУЖНОЙ ТЕРАПИИ. МеДИЦИнСКИЙ веСтнИк Северного Кавказа. 2018;13(3):566-571. DOI - https://doi.org/10.14300/mnnc.2018.13106

Er - Erbium

IPL - Intense Pulsed Light

QoL - Quality of Life
UV - Ultraviolet Radiation

25OHD - 25-hydroxyvitamin D tretch marks are manifestations of epidermal atrophy and result from tissue damage due to excessive tension [1, 2]. Stretch marks are one of the most common skin lesions for both women and men. The most frequent places of their locations are the abdomen, buttocks, thighs, chest, sleep, armpits and groin. Striae are divided according to the type and etiology on atrophic, stretch marks be-belt, linear stretch marks, red stretch marks, white striae, striae black and dark blue $[3,4]$.

Blue and black stretch marks are less common than other clinical types of stretch marks, especially among patients with dark skin phototypes due to the increasing saturation of melanin and in the foci $[5,6]$. Due to its location in a particular anatomical region for stretch marks is characterized by the following pattern. Pragnacy stretch marks are predominantly localised in the abdominal area and on the breast; the adolescent stretch marks are localised on the thighs and in the lumbosacral region; nonpregnant young women get stretch marks mainly in the chest area and hips [5, 7, 8]. Most often striae are perpendicular to the lines of Langer, in directions with a minimum capacity of the skin to stretching $[1,2]$.

Striae represent linear atrophic scars, able despite the small area and, most often, the localization at closed clothing parts of the body, cause significant psychological difficulties and lower quality of life due to aesthetic concerns, and because of such subjective symptoms as itching $[5,9,10,11]$.

Thus, cross-sectional study of quality of life of Japanese pregnant women with striae showed that overall quality of life was not significantly different between women with stretch marks, and not having such. Howev- 
er, women with severe clinical manifestations of stretch marks mentioned the worse quality of life on a scale of HRQoL [12].

Most doctors consider this patology as a cosmetic defect, and not as a disease, without giving due importance to this problem [2, 12, 13]. In addition, the patients themselves, as was found, consult preferably the beauticians, rather than the dermatologists [11]. A large category of patients uses other sources of information (not medical) searching for means of treatment and prevention of stretch marks [14]. The most frequently mentioned source of information was the advice of friends, family members and Internet sources [14].

The pathogenesis of striae are disorders of elastic fibers, fibrils of collagen and other extracellular membrane components. Examination of biopsy specimens showed the disorganization, reduction and thinning of collagen elastin fibers and thinning of the dermis in comparison with the tissue samples of intact skin [2, 13, 15]. The activity of fibroblasts is reduced in striae decreasing fibronectin and expression of procollagen I and III [16].

In the course of study of influence of metabolic disorders it was found that the expression of hormone receptors is increased in the areas of skin exposed to mechanical stress - tensile. That is, in the opinion of some authors, the basis for the formation of stretch marks. Increased activity of hormone receptors occurs within the period of the formation of stretch marks and their functional level depends on the stage of development of stretch marks. Expression of the estrogen receptor is two times higher than that in the areas of intact skin, along with increased expression of receptors of androgens and glucocorticoids [13].

Its etiology and pathogenesis is a multifactorial disease with not completely established reasons [5]. Some stages of the pathogenesis of striae similar to those for scar formation $[5,8]$.

It is also reported about the role of disorders of vitamin $D$ metabolism in the development of stretch marks. Violation of exchange of vitamins plays an important role in the pathogenesis and influence the course of many chronic dermatoses [17]. Currently, it is proved that the physiological significance of the status of vitamin $D$ is not only in the regulation of bone metabolism [4]. A large number of recently published clinical studies explain the important role of vitamin $D$ in the regulation of many physiological functions and describe the relationship between low levels of vitamin $\mathrm{D}$ and its metabolites in the development of many diseases. Vitamin $D$ deficiency can be attributed to the pandemic $[18,19]$. The main source of vitamin $D$ in the body in all ages is the exposure to the sun. Throughout life, vitamin $\mathrm{D}$ plays a crucial role in maintaining and developing a healthy body. There are still differences regarding the serum level of 25 -hydroxyvitamin D (25OHD), sufficient both for bone health and to reduce the risk of diseases associated with vitamin D deficiency [20,21]. Normal levels of vitamin $D$ in the skin helps to improve the flow acne, increase skin elasticity, stimulate the production of dermal collagen and reducing the risk of development of malignant skin diseases [22, 23, 24].

Returning to the theme of enhanced expression of hormone receptors in the foci of stretch marks, include the following data. There is evidence demonstrating the beneficial role of vitamin $D$ in the biosynthesis of hormones and negative role in the regulation of expression of estrogen receptors, i. e., hypovitaminosis D leads to an increasing expression of estrogen receptors. Perhaps this is the explanation of the more frequent development of striae among women with low vitamin D levels $[25,26]$.
Among the main risk identified factors were the following: genetic predisposition, aggravated by the formation of stretch marks family history [7].

Among diseases and conditions associated with the formation of striae identified were the following: a condition requiring systemic or topical use of corticosteroids, pregnancy, adolescence, change of weight, hypercortisolism, Marfan syndrome, intoxication, connective tissue disease (e.g., congenital dolichostenomelia) [8, 13, 16]. In addition, stretch marks may develop after some plastic surgeries. Thus, in the related PubMed and SciELO noted the incidence of stretch marks is 4.6 to $7 \%$ after augmentation mammoplasty (quick mechanical stretching caused by the insertion of the implant) $[13,27]$.

According to other recent studies, the geographic position and environmental factors influence a lot the formation of striae. These studies show a minor influence of the age of the patient $[28,29]$.

One of the most commonly trigger the development of stretch marks is pregnancy. It is found that stretch marks occur in 55-90\% of pregnant women [30]. According to other authors, pregnant women stretch marks occur in $90 \%$ of cases. In addition to the mechanical stretching of skin during pregnancy the appearance of stretch marks, contribute to hormonal changes [16, 29]. As predisposing factors by many researchers, stand out: positive family history for stream, rapid weight gain during pregnancy, young age of pregnant women with a high body mass index and high birth weight [11].

E. Ersoy et al. (2016) was selected risk factors for the development of striae during pregnancy. The study included 211 pregnant with a single fetus of women hospitalized before delivery, with absence of systemic diseases or other risk factors, for example, hydramnion. The following predisposing to the formation of stretch marks factors: young age, increased body mass index before pregnancy, weighed down by the formation of striae, family history, male gender of a fetus, low levels of education. The smoking, the skin phototype, the amount of fluid per day and the level of financial wealth does not significantly affect the risk of developing stretch marks. In this study, prophylactic use of topical treatments did not affect the development of stretch marks [31].

Kasielska-Trojan A. et al. (2015) surveyed 299 women living in the Caucasus in the period up to 6 months after childbirth. The study included mothers as the first time, women giving birth two or more times. Among the risk factors of striae were identified as follows: the appearance of stretch marks in history, weighed down by the formation of striae, family history, increased body mass index before pregnancy, no chronic diseases, increased birth weight, the presence of stretch marks on the breast (the development of stretch marks from $71.4 \%$ of women with stretch marks on to the same breast versus $28.6 \%$ of women lack thereof), absence of striae on the skin of the thighs (combined with striae in the hips in $23 \%$ and with their absence, $77 \%$ ). Treatment with progesterone did not affect the formation of stretch marks [29].

Picard D. et al. (2015) examined 800 nulliparous women in the postpartum period. The average age was 26.3 years. Among the risk factors for the stretch marks were defined young age, high weight before pregnancy, high body mass index, increased weight during pregnancy, fast weight gain, I and IV skin phototypes according to Fitzpatrick, the lack of a permanent job, burdened by education a family history of stretch marks. External treatment of striae was noted as an effective [30].

Despite the coincidence of the results of many studies, there are contradictory data. Thus, in particular, some studies have shown that obesity before pregnancy 
is a significant risk factor for the development of striae; however, other studies did not describe this fact as significantly significant [30].

Today there is a wide range of therapeutic methods ranging from the external means to the surgical methods of treatment of stretch marks; however, there is no universal remedy with a high level of evidence of clinical effect, however, proved that only an increase of the connective tissue is an effective way to prevent stretch marks $[6,8,32]$.

Different studies provide data on the effectiveness of therapy topical retinoids (tretinoin), medications containing glycolic acid, trichloroacetic acid, silicone gel, some cosmetic drugs and non-pharmacological treatments such as microdermabrasion, radiofrequency: ablation, laser and surgical techniques (photothermolysis, IPL-technique, fractional laser, ablative and non-ablative laser therapy, etc.) [2, 8, 13, 33, 32, 35].

Laser therapy. Pulsed dye laser leads to clinical improvement, but is a limited method in respect of white stretch marks. This kind of laser therapy can be useful in the treatment of red stretch marks by reducing hyperemia [36].

Malekzad F. et al. (2014) conducted a study examining the efficacy and safety of non-ablative fractional laser $1540 \mathrm{~nm}$. The study included 10 women correspond 2650 years III-V phototypes of skin according to Fitzpatrick, who had striae alba. Following treatment, a statistically significant clinical improvement in the course of striae ranged from 1 to $24 \%$. The differences in the results of treatment of 4 weeks and 16 weeks in favor of the latter. The patients noted marked improvement in comparison with the control group. Of unwanted effects have been noted dim post-inflammatory hyperpigmentation in one patient, after 8 weeks of treatment and light acne after 4 weeks of therapy. Pronounced clinical effect was maintained for 3 months [37].

Among the most studied fractional lasers in the treatment of striae was non-ablative erbium (Er): Glass and ablative $\mathrm{CO} 2$ laser. On average, an improvement of 50$75 \%$ was observed after 2-6 treatments therapy non-ablative Er:Glass laser [38].

Phototherapy. Phototherapy gives good results in the treatment of stretch marks. The main methods include intense pulsed light (IPL), ultraviolet radiation (UV) and infrared. According to Al-Dhalimi et al. (2013), IPL therapy leads to improvement of the skin process, however, has no such undesirable phenomena as formation of persistent erythema and post-inflammatory hyperpigmentation. UV therapy, in particular, the combination of UV-A and UV-B spectrum, lead has been shown to pigmentation of white stretch marks [35, 39].

Cosmetic techniques. Is a process and clean the abrasive components of the affected area of the skin. Microdermabrasion and phonophoresis improves over the striae, however, studies have shown that injection techniques have an even greater statistically significant efficacy. Injection therapy causes a controlled damage to the skin with subsequent stimulation of the synthesis of collagen and elastin in the papillary layer of the dermis [40].

External therapy. Topical drugs used for the prevention and treatment in the early stages of formation of stretch marks mainly stimulate the following processes: increased activity of fibroblasts, increased production of collagen and fibronectin, improved blood perfusion, and anti-inflammatory effect and stimulation of cell proliferation $[6,33]$. These effects improve skin texture, consequently, increase the skin's moisture, elasticity and increased thickness of the dermis.

Despite the presence on the pharmaceutical market, a large number of topical drugs, to date there is no standard treatment of stretch marks, the evidence of the clinical efficacy of most funds is limited [11, 33, 41, 42]. Increasing the elasticity of connective tissue is one of the main objectives of topical therapy of stretch marks along with increased collagen production, anti-inflammatory and rehydration of the skin, which in turn contributes to the elasticity of the skin and its hydration $[6,43]$.

The thickness of the epidermis and dermis, and the density of the skin are important parameters characterizing the process of skin regeneration and hydration of the skin and increase its elasticity are of great importance for the prevention of stretch marks and improve the appearance of the skin [44].

The review found that $78.2 \%$ of Japanese women use during pregnancy is one or several tools for the treatment and prevention of stretch marks [45]. It was also found that the majority of them were primipara. Aged primiparas may be more motivated to attempt to prevent and reduce the severity of stretch marks. It was shown in the survey where it was noted that aged primiparas more often applied to the outer means for the prevention of stretch marks [45].

In the study of Garcia Hernandez J. A. et al. (2013) analyzed the effectiveness of therapy by some external means. The study included 183 pregnant women aged over 18 and with a pregnancy $12+/-2$ weeks. All patients of the main group used a cream containing hydroxyprolisilane, rosehip oil, Centella asiatica triterpenes and vitamin E. Applied it 2 times a day from 12 weeks of pregnancy. This method of therapy was effective in women without striae in history (during the treatment of striae occurred in $6 \%$ of patients versus $35 \%$ in the control group of patients treated with placebo). The severity of the available to research stretch marks increased in the control group observations. In the main group, the severity has not changed. Among patients in the control group, had a more severe course of the newly emerging stretch marks in comparison with the group of patients treated with the above therapy [8, 33, 34, 35, 42].

Demonstrated the effectiveness of creams with hyaluronic acid in combination with vitamins and essential fatty acids "Alphastria» and "Verum». Hyaluronic acid is the active ingredient in both drugs and increases the resistance of the skin to mechanical stretching; prevent atrophy by stimulating the activity of fibroblasts and collagen [9].

The study Soltanipour F. et al. (2012) evaluated the effectiveness of olive oil in the treatment and prevention of stretch marks. The study included 100 previously nulliparous pregnant women, 50 of whom had received treatment and 50 № The treatment consisted in applying to the skin of the abdomen of olive oil twice a day. The frequency of striae with severe clinical manifestation was lower in the group of patients who used olive oil. However, the differences were not statistically significant [46].

In a later placebo-controlled study by the same authors (2014) evaluated the effectiveness of olive oil in comparison with the cream «Saj», which is composed of lanolin, stearin, triethanolamine, almond oil, glycerin and bisoux amidin. The study included 150 previously nulliparous pregnant women in second trimester of pregnancy, 50 patients in each group. In the group of patients, to apply olive oil on striae occurred in $72 \%$; in female patients, causing the cream «Saj» $-64 \%$; in the group of patients who used a placebo $60 \%$. The differences were not statistically significant [47].

In the study of Timur Tashan S. et al. (2012) estimated the effectiveness of almond oil, which was applied every other day from 19 to 32 weeks of gestation and 33 weeks daily until delivery. In the control group, the treatment was 
carried out. The study included 141 female patients from Turkey. All study participants were primipara. The study was conducted from 1 February 2010 to 15 April 2011. 47 patients rubbed oil massaging the skin for $15 \mathrm{mi}-$ nutes, 48 patients applied the oil without massage, 46 patients constituted the control group. The detection rate of stretch marks was as follows: $20 \%$ in women who used the oil to massage skin; 38.8 per cent among women, causing the oil without massage; $41.2 \%$ in the control group. The use of almond oil could significantly reduce the risk of stretch marks in comparison with the placebo group [48].

A double-blind controlled study conducted by UdDin S. et al. (2013) presents the efficacy of within 6 weeks use of silicone gel in striae rubrae and albae. The efficacy was evaluated clinically and histologically. It was shown that in the centers observed decrease in the intensity of blood supply, hemo-globin, and reduced elasticity, and increased pigmentation [8].

It is also reported about the effectiveness of treatment with preparations containing Vitamin $\mathrm{C}$ together with moisturizers in the treatment of striae rubrae $[8,33$, 34, 35, 43]

Pomegranate seed oil is a rich source of conjugated fatty acids, flavonoids and anthocyanins (delphinidin, cyanidin and pelargonidin) with antioxidant and anti-inflammatory effects and are widely used in anti-aging medicine and in the treatment of stretch marks in particular [41]. Antioxidant activities of pomegranate seed 3 times higher in comparison with green tea extract [49]. So, set a positive therapeutic effect in diabetes and irritable bowel syndrome [50].

Among other herbal remedies, it should be noted Croton lechleri, with antioxidant, anti-inflammatory properties thanks to its composition proanthocyanidins, catechin, epigallocatechin and epicatechin. Studies have shown that the preparation stimulates the proliferation and migration of fibroblasts, production of collagen and regeneration of the epithelium. In addition to the therapeutic effects of striae, herbal drug has such effect, e, as healing, antibacterial, antiviral, anti-inflammatory and antioxidant [51]
Its effectiveness in preventing the stretch marks showed emollients - water emulsion in oil (Argan oil) [52]. Rheological properties of emulsions allow the preparation to have long-term stability when applied, and acceptable organoleptic properties contribute to the compliance to the drug [53]. In the studies there was a significant reduction in the time of the retraction of the skin (569.33 $\pm 146.3 \mathrm{~ms}$ vs $720.42 \pm 108.08 \mathrm{~ms}$ patients in the control group, not using emollients) that talks about the improvement of skin elasticity [54, 55]. The composition of these drugs can include emollients, like mineral oil, cocoa butter, Caprylic/Caprylic triglycerides, glyceryl stearate, beeswax, cetylstearyl alcohol and glycerin as a moisture retaining agent (occlusion and hydration) [56]. Part of the triethanolamine is used to increase viscosity and neutralization of carbopol [57].

Conclusions. Nowadays many methods of therapy and prevention of the formation of stretch marks are known. Despite the results of numerous studies there is no exhaustive data on the etiology and pathogenesis of striae. Overweight, pregnancy, a family history of striae, number of associated diseases, of course, plays an important role in the development of stretch marks. However, the results of some studies (particularly the study of the expression of hormonal receptors in the lesions and also to study the effect of vitamin D on the formation of stretch marks) represent a broader view of this problem. Local moisturizer is widely discussed as the main means of prevention of striae. The techniques of laser therapy and injection therapy are described in the literature as the most promising means of treatment. The latter are widely used in dermatology and cosmetology. Convincing data was obtained by S. Wilson et al. when used as the primary method of treatment papules-pustular form of acne local injections of acidic peptidoglycan of plant origin. It was achieved significant clinical effect [58]. Therefore, striae are medical and social problem, with a limited set of means of treatment and prevention. This fact requires a search for new means and methods, as well as a deeper study of the mechanisms of pathogenesis.

Disclosures:

The authors declare no conflict of interest.

\section{References}

1. Stamatas G. N., Lopes-DaCunha A., Nkengne A., Bertin C. Biophysical properties of striae distensae evaluated in vivo using non-invasive assays. Skin Research and Technology. 2015;21(2):254-258 https://doi.org/10.1111/srt.12186

2. Lemperle G., Tenenhaus M., Knapp D., Lemperle Sm. I. The direction of optimal skin incisions derived from striae distensae. Plastic and reconstructive surgery. 2014;134(6):1424-1434. https://doi.org/10.1097/01.prs.0000438462.13840.21

3. Oakley A. M., Bhimji S. S. StatPearls [Internet]. Treasure Island (FL): StatPearls Pulishing; 2018-2017 May 28. PMID: 28613776.

4. Aldahan A. S., Shah V. V., Mlacker S., Samarkandy S., Alsaidan M. [et al.] Laser and Light Treatments for Striae Distensae: A Comprehensive Review of the Literature. Am. J. Clin. Dermatol. 2016;17(3):239-256. https://doi.org/10.1007/s40257-016-0182-8

5. Bleve M., Capra P., Pavanetto F., Perugini P. Ultrasound and 3D skin imaging: methods to evaluate efficacy of striae distensae treatment. Dermatol. Res. Prat. 2012; 2012:673706.

6. Brennan M., Young G., Devane D. Topical preparations for preventing stretch marks in pregnancy. Cochrane Database Syst. Rev. 2012;11:CD000066.
7. Al-Himdani Ud-Din S., Gilmore S., Bayat A. Striae distensae: a comprehensive review and evidence-based evaluation of prophylaxis and treatment. Br. J. Dermatol. 2014;170(3):527-547.

8. Ud-Din S., McAnelly S. L., Bowring A., Whiteside S., Morris J. [et al.] A double-blind controlled clinical trial assessing the effect of topical gels on striae distensae (stretch marks): a non-invasive imaging, morphological and immunohistochemical study. Arch. Dermatol. Res. 2013;305(7):603-617. https://doi.org/10.1007/s00403-013-1336-7

9. Korgavkar K., Wang F. Stretch marks during pregnancy: a review of topical prevention. Br. J. Dermatol 2015;172:606-615.

10. Park K. K., Murase J. E. Connective Tissue Changes. in: G. Kroumpouzos (Ed.) Text Atlas of Obstetric Dermatology. Vol 1. Har/Psc ed. LWW, 2013.

11. Bahrami N., Soleimani M. A., Nia H. Sh., Masoodi R. Shaigan $\mathrm{H}$. [et al.] Striae gravidarum in Iranian women prevalence and associated factors. Life Sci. J. 2012; 9(4):3032-3037.

12. Yamaguchi K., Suganuma N., Ohashi K. Quality of life evaluation in Japanese pregnant women with striae gravidarum A cross-sectional study. BMC Res. Notes. 2012:5:450.

13. Valente D. S., Zanella R. K., Doncatto L. F., Padoin A. V. Incidence and risk factors of striae distensae following 
breast augmentation surgery: a cohort study. PLOS ONE. 2014;9(5):e97493.

https://doi.org/10.1371/journal.pone.0097493

14. Grimes H. A., Forster D. A., Newton M. S. Sources of information used by women during pregnancy to meet their information needs. Midwifery.2014;30(1):26-33. https://doi.org/10.1016/j.midw.2013.10.007

15. Wang F., Calderone K., Smith N. R., Do T. T., Helfrich Y. R. [et al.] Marked disruption and aberrant regulation of elastic fibres in early striae gravidarum. Br. J. Dermatol. 2015:173:1420-1430.

16. Gilmore S. J., Vaughan B. L., Madzvamuse A. Jr., Maini P. K. A mechanochemical model of striae distensae. Math. Biosci. 2012;240(2):141-147.

17. Tishchenko L. D., Khaddad S. M., Tishchenko A. L. Thiamin deficit in psoriatic patients abusing alcohol. Vestnik Dermatologii i Venerologii. 1995;5:40.

18. Sahbaz A., Aynioglu O., Isik H., Gulle K., Akpolat F. M. [et al.] Cholecalciferol (vitamin D3) prevents postoperative adhesion formation by inactivating the nuclear factor kappa B pathway: a randomized experimental study. Journal of Surgical Research. 2015;198(1):252-259

https://doi.org/10.1016/j.jss.2015.05.010

19. Upala S., Sanguankeo A., Permpalung N. Significant association between vitamin $D$ deficiency and sepsis: a systematic review and meta-analysis. BMC Anesthesiology. 2015;15:84

https://doi.org/10.1186/s12871-015-0063-3

20. Samochocki Z., Bogaczewicz J., Jeziorkowska R., SysaJędrzejowska A., Glińska O. [et al.] Vitamin D effects in atopic dermatitis. Journal of the American Academy of Dermatology. 2013;69(2):238-244. https://doi.org/10.1016/j.jaad.2013.03.014

21. Wacker M., Holiack M. F. Vitamin D-effects on skeletal and extraskeletal health and the need for supplementation. Nutrients. 2013;5(1):111-148. https://doi.org/10.3390/nu5010111

22. Reddy K. K., Gilchrest B. A. The role of vitamin D in melanoma prevention: evidence and hyperbole. Journal of the American Academy of Dermatology. 2014;71(5):1004-1005 https://doi.org/10.1016/j.jaad.2014.08.013

23. Curiel-Lewandrowski C., Tang J. Y., Einspahr J. G. [et al.] Pilot study on the bioactivity of vitamin D in the skin after oral supplementation. Cancer Prevention Research (Phila). 2015;8(6):563-569.

24. Soleymani T., Hung T., Soung J. The role of vitamin D in psoriasis: a review. International Journal of Dermatology. 2015;54(4):383-392. doi: 10.1111/ijd.12790

25. Chang E. M., Kim Y. S., Won H. J., Yoon T. K., Lee W. S. Association between sex steroids, ovarian reserve, and vitamin $D$ levels in healthy nonobese women. The Journal of Clinical Endocrinology \& Metabolism. 2014; 99(7):2526-2532 https://doi.org/10.1210/jc.2013-3873

26. Narvaez C. J., Matthews D., LaPorta E., Simmons K. M. Beaudin S. [et al.] The impact of vitamin D in breast cancer: genomics, pathways, metabolism. Frontiers in Physiology. 2014:5:213.

https://doi.org/10.3389/fphys.2014.00213

27. Guimarães P. A. M., Haddad A., Sabino Neto M., Lage F. C., Ferreira L. M. [et al.] Striae distensae after breast augmentation: treatment using the nonablative fractionated 1550-nm erbium glass laser. Plastic and Reconstructive Surgery. 2013;131(3):636-642. https://doi.org/10.1097/prs.0b013e31827c7010

28. Narin R., Nazik H., Narin M. A., Nazik E., Özdemir F. [et al.] Can different geographic conditions affect the formation of striae gravidarum? A multicentric study. J. Obstet. Gynaecol. Res. 2015;41(9):1377-1383. https://doi.org/10.1111/jog.12741

29. Kasielska-Trojan A., Sobczak M., Antoszweski B. Risk factors of striae gravidarum. Int. J. Cosmet. Sci. 2015;37:236-240.

30. Picard D., Sellier S., Houivet E., Marpeau L., Fournet P. [et al.] Incidence and risk factors for striae gravidarum. J. Am. Acad. Dermatol. 2015;73:699-700.

31. Ersoy E., Ersoy A. O., Celik Y. E., Tokmak A., Ozler S. [et al.] Is it possible to prevent striae gravidarum? J. Chin. Med. Assoc. 2016;79:272-275.
32. Nassar A., Ghomey S., El Gohary Y., El-Desoky F. Treatment of striae distensae with needling therapy versus microdermabrasion with sonophoresis. J. Cosmet. Laser Ther. 2016;18:330-334.

33. Ud-Din S., McGeorge D., Bayat A. Topical management of striae distensae (stretch marks): prevention and therapy of striae rubrae and albae. J. Eur. Acad. Dermatol. Venereol. 2016:30(2):211-222.

34. Mazzarello V., Farace F., Ena P. [et al.] A superficial texture analysis of $70 \%$ glycolic acid topical therapy and striae distensae. Plast. Reconstr. Surg. 2012;129(3):589-590.

35. Al-Dhalimi M. A., Abo Nasyria. A. A. A comparative study of the effectiveness of intense pulsed light wavelengths $(650 \mathrm{~nm}$ vs $590 \mathrm{~nm}$ ) in the treatment of striae distensae. J. Cosmet. Laser Ther. 2013;15:120-125.

36. Aldahan A. S., Shah V. V., Mlacker S., Samarkandy S., Alsaidan M. [et al.] Laser and light treatments for striae distensae: A comprehensive review of the literature. Am. J. Clin. Dermatol. 2016;17:239-256.

37. Malekzad F., Shakoei S., Ayatollahi A., Hejazi S. The safety and efficacy of the $1540 \mathrm{~nm}$ non-ablative fractional XD probe of star lux 500 device in the treatment of striae Alba: Before-after study. J. Lasers Med. Sci. 2014;5:194-198.

38. Tretti Clementoni M., Lavagno R. A. Novel 1565 nm nonablative fractional device for stretch marks: A preliminary report. J. Cosmet. Laser Ther. 2015;17:148-155.

39. Farahnik B., Park K., Kroumpouzos G., Murase J. Striae gravidarum: Risk factors, prevention, and management Int. J. Womens Dermatol. 2017;3(2):77-85 https://doi.org/10.1016/j.ijwd.2016.11.00

40. Nassar A., Ghomey S., El Gohary Y., El-Desoky F. Treatment of striae distensae with needling therapy versus microdermabrasion with sonophoresis. J. Cosmet. Laser Ther. 2016:18:330-334.

41. Jadoon S., Karim S., Bin Asad M. H. [et al.] Anti-aging potential of phytoextract loaded-pharmaceutical creams for human skin cell longetivity. Oxid Med. Cell. Longev. 2015;2015:709628.

42. Hernández G. J. A., González M. D., Castillo P. M., Figueras F. T. Use of a specific anti-stretch mark cream for preventing or reducing the severity of striae gravidarum. Randomized, double-blind, controlled trial. Int. J. Cosmet. Sci. 2013;35:233-237.

43. Alaiti S., webpage on the Internet Striae Distensae Treatment \& Management. Accessed July 26, 2016. [cited May 20, 2015]. Available at: http://emedicine medscape.com/article/1074868-treatment

44. Crisan D., Crisan M., Moldovan M., Lupsor M., Badea R. Ultrasonographic assessment of the cutaneous changes induced by topical flavonoid therapy. Clin. Cosmet. Investig. Dermatol. 2012:5:7-13.

45. Yamaguchi K., Suganuma N., Ohashi K. Prevention of striae gravidarum and quality of life among pregnant Japanese women. Midwifery. 2014;30(6):595-599. https://doi.org/10.1016/j.midw.2013.07.011

46. Soltanipour F., Delaram M., Taavoni S., Haghani H. The effect of olive oil on prevention of striae gravidarum: A randomized controlled clinical trial. Complement Ther. Med. 2012;20:263-266

47. Soltanipour F., Delaram M., Taavoni S., and Haghani H. The effect of olive oil and the Saj cream in prevention of striae gravidarum: A randomized controlled clinical trial. Complement Ther. Med. 2014;22:220-225.

48. Timur Taşhan S., Kafkasli A. The effect of bitter almond oil and massaging on striae gravidarum in primiparous women. J. Clin. Nurs. 2012;21:1570-1576.

49. Rahimi H. R. Arastoo M. Ostad S. N. A comprehensive review of Punica granatum (Pomegranate) properties in toxicological, pharmacological, cellular and molecular biology researches. Iran J. Pharm. Res. 2012;11(2):385400.

50. Lauche R., Kumar S., Hallmann J. [et al.] Efficacy and safety of ayurvedic herbs in diarrhoea-predominant irritable bowel syndrome: a randomised controlled crossover trial. Complement Ther. Med. 2016;26:171177.

51. Namjoyan F., Kiashi F., Moosavi Z. B., Saffari F., Makhmalzadeh B. S. Efficacy of Dragon's blood cream on wound healing: a randomized, double-blind, placebocontrolled clinical trial. J. Tradit. Complement Med. 2015;6(1):37-40. 
52. Djuris J., Vasiljevic D., Jokic S., Ibric S. Application of D-optimal experimental design method to optimize the formulation of $\mathrm{O} / \mathrm{W}$ cosmetic emulsions. Int. J. Cosmet. Sci. 2014;36(1):79-87.

53. Lukic M., Jaksic I., Krstonosic V., Cekic N., Savic S. A combined approach in characterization of an effective W/O hand cream: the influence of emollient on textural, sensorial and in vivo skin performance. Int. J. Cosmet. Sci.2012;34(2):140-149.

54. Kozel B. A., Bayliss S. J., Berk D. R. [et al.] Skin findings in Williams syndrome. Am. J. Med. Genet A. 2014;164A (9):2217-2225.

55. Hadi H., Awadh A. I., Hanif N. M., Md Sidik N. F., Mohd Rani M. R. [et al.] The investigation of the skin biophysical measurements focusing on daily activities, skin care habits, and gender differences. Skin. Res. Technol. 2016;22(2):247-254.

56. Rawlings A. V., Bielfeldt S., Lombar K. J. A review of the effects of moisturizers on the appearance of scars and striae. Int. J. Cosmet. Sci. 2012;34(6):519-524.

57. Chularojanamontri L., Tuchinda P., Kulthanan K., Pongparit K. Moisturizers for acne: what are their constituents? J. Clin. Aesthet. Dermatol. 2014;7(5):36-44.

58. Vil'son S., Tishchenko A. L., Gorskii V. S. Assessment of the ability of lymphocytes to activate background local injections of acidic peptidoglycan in patients with acne. Klinicheskaja dermatologija i venerologija. 2015;(3):14: 37-39.

\section{About authors:}

Tishchenko Andrei Leonidovich, MD, PhD, Professor, Head of the Department of skin and venereal diseases; tel.: +79257715540; e-mail: 7715540@gmail.com

Gorskii Vladimir Sergeevich, PhD, associate Professor of the Department of skin and venereal diseases; tel.: +79202723338; e-mail: drgorskiy@mail.ru

Sergeeva Natalia Sergeevna, PhD, associate Professor of the Department of skin and venereal diseases; tel.: +79057803333; e-mail: kosmetolog.rudn@gmail.com 